\title{
Narratives of Murder and Knowledge: Pellegrino Artusi and Dante Alighieri as Sleuths
}

\section{Mirna Cicioni}

\begin{abstract}
Summary: Using McHale's notions of "epistemological" and "ontological" dominants, this article analyzes three historical crime novels that have real historical characters as their protagonist: Marco Malvaldi's Odore di chiuso (2011), featuring Pellegrino Artusi as the detective, and Giulio Leoni's I delitti del mosaico (2004) and La crociata delle tenebre (2007), with Dante Alighieri as the sleuth. The article shows how the hybridization of crime fiction, history, and biography may be a fertile ground for the representation of the different ways of "knowing" in their respective historical periods and the construction of a dialogue between past and present constructed around depictions of social and political diversity, language issues, and ideas of "Italy."
\end{abstract}

Historical crime fiction is at the intersection of historical fiction and crime fiction, establishing a dialogue with both genres. With historical fiction it shares the representation of past periods and the re-evaluation of past events, informed by subsequent ideologies and theories; in the well-known words of Italo Calvino, "il romanzo storico può essere un ottimo sistema per parlare dei propri tempi e di sé" (1528). With crime fiction, it shares a focus on solving crimes and analyzing the social changes and conflicts that are the background of each crime.

Acquiring and questioning knowledge is a shared central feature of all three genres. The appeal of historical fiction lies in the tension between what was known and believed in the period in which the fictional narrative is set, what was known and believed at the time the fictional text was written, and what is known and believed by contemporary readers, when they try to read the past in terms of their present. ${ }^{1}$ Evaluating knowledge, through clues, hypotheses, misunderstandings, and false trails, is the basic feature of crime fiction, which is seen by many scholars

\footnotetext{
${ }^{1}$ See Fabio Del Bosco (35-37).
} 
as - in the words of the postmodern theorist Brian McHale- "the epistemological genre par excellence" (9). A similar view is put forward by Umberto Eco in his "Postille a Il nome della rosa": "[La trama] piú metafisica e filosofica [è] il romanzo poliziesco [...] Il romanzo poliziesco rappresenta una storia di congettura, allo stato puro" (524). In historical crime fiction, the knowledge, values, and beliefs of the time of the narrative affect the murderer's motives, especially when the plot revolves around issues, such as the power of religious institutions, the status of women, contacts between different cultures, that are still relevant in the readers' time. The knowledge eventually gained may be neat and reassuring (as it usually is in the conclusions of "classic murder mysteries," also known as "clue-puzzle mysteries") ${ }^{3}$ or problematic and destabilizing, with "guilty parties" being economic, political, or religious institutions (as they tend to be in noir novels) rather than individuals. ${ }^{4}$

Historical crime fiction has been examined in depth by relatively few scholars. Useful analytical perspectives are provided by Stefano Tani, in his analysis of postmodern American and Italian detective novels The Doomed Detective, and by John Scaggs in his Crime Fiction. This essay draws on both, as well as on McHale's notions of "epistemological" and "ontological" dominants. Using Roman Jakobson's concept of dominants (central components of works of art), McHale (6-11) argues that the main feature of modernist crime fiction is an "epistemological dominant," that is to say, various strategies that foreground questions on the nature, reliability, and transmission of knowledge, and that the main feature of postmodernist fiction is an "ontological dominant": various strategies that foreground questions on the nature of the fictional world constructed by the text.

In most historical crime fiction, the sleuths are fictional characters, whether professional investigators such as Steven Saylor's Gordianus the Finder, Lindsey Davis' Marcus Didius Falco, and Carlo Lucarelli's Commissario De Luca in a

\footnotetext{
${ }^{2}$ See Mandel (21-26); Reuter (21-26); Comastri Montanari (85-100); Rushing (44); and Scaggs (46-50).

${ }^{3}$ See Reuter (28-35), who uses the term roman à enigme; and Stephen Knight, who uses clue-puzzle ("The Golden Age" 77). Comastri Montanari uses giallo classico or giallo allinglese (85-86). Both Reuter and Knight refer to Carlo Ginzburg's important 1979 essay “Spie. Radici di un paradigma indiziario," which argues that spie (clues) constitute the foundation of a new epistemological paradigm that at the turn of the twentieth century began to gain ground in art history (with Giovanni Morelli), psychoanalysis (with Freud), and literature (with Conan Doyle).

${ }^{4}$ See Galli (x-xi); Scaggs (139-43); Wu Ming 2 (20-24); and Perissinotto (6-7).
} 
series of novels set in fascist Italy, or individuals with better-than-average enquiring minds and the ability to make unexpected connections, such as Danila Comastri Montanari's Senator Publius Aurelius Statius, Ellis Peters' Brother Cadfael, and Umberto Eco's William of Baskerville. Sometimes, however, the amateur sleuths are recognizable historical figures, often authors of literary or philosophical works. As the murder plots interweave both with historical events and with what is known about the historical figure's life, there is a genre intersection between crime fiction, history, and biography. Among many other such texts, I can mention Stephanie Barron's series featuring Jane Austen; the Canadian academic Margaret Doody's series about Aristotle; Peter Heck's series revolving around Mark Twain (with playful titles such as Death on the Mississippi and The Guilty Abroad); and Jed Rubenfeld's The Interpretation of Murder and The Death Instinct, where Sigmund Freud does not do any actual detecting, but manages to deduce the right conclusion on the basis of his own theories. In Italy, the growth of historical crime fiction is a relatively recent phenomenon, which began after the world-wide success of Umberto Eco's Il nome della rosa in 1980 (translated as The Name of the Rose in 1983). Over thirty years later, there is a large and diversified corpus of novels, several of which feature non-fictional sleuths. These include three novels by the Florentine Leonardo Gori (Le ossa di Dio, La città del sole nero, and La città d'oro), set in early-sixteenth-century Florence, where complex plots are discovered by Niccolò Machiavelli; Eresia e delitto. Un giallo medievale by Giuseppe Mazzanti, set in 1113, where the sleuth is the theologian (and saint) Bernard of Clairvaux; and a trilogy (Sempre caro, Sangue dal cielo, and L'altro mondo) by the Sardinian Marcello Fois, where murders in Sardinia at the end of the nineteenth century are solved by the lawyer and poet Sebastiano Satta.

As in all historical fiction, the use of historical figures is subject to restraints: their characteristics and actions must not contradict what is known about their lives, and the representations of the culture of their times must not be at odds with what is known about those periods. ${ }^{5}$ However, sometimes biographical facts may be "manipulated or subverted" through the addition of more or less plausible fictional details. ${ }^{6}$ The biography of a well-known historical figure may contain elements interesting to contemporary readers (Dante's short temper, Jane Austen's cool rational mind, Mark Twain's financial problems and speaking engagements),

\footnotetext{
${ }^{5}$ See Eco, "Postille” (532); McHale (86-89); and Ellen O’Gorman (19-26).

${ }^{6}$ See Vickers (214); O'Gorman (125); and Scaggs (26-28).
} 
or readers may be curious about how the historical figure's known character traits and specialist knowledge will help her or him discover one or more murderers. As Claudio Milanesi argues, the connections between biographical, cultural, and genre-based knowledges produce complex networks of intertextual references (17-18), particularly when the main historical figure is a writer whose works can be alluded to, mentioned, and quoted.

This essay examines three best-selling historical crime novels published between 2004 and 2011. In Odore di chiuso, by Marco Malvaldi (2011), the amateur sleuth is Pellegrino Artusi, the well-known author of La scienza in cucina e l'arte di mangiar bene (1891). I delitti del mosaico (2004) and La crociata delle tenebre (2007) are the second and fourth of five novels by Giulio Leoni that revolve around intrigues uncovered at the beginning of the fourteenth century by Durante degli Alighieri, better known as Dante. ${ }^{7}$ Although different in form and content, these three texts construct similar implied readers: educated at least to the level of liceo, curious about science (and, in Leoni's case, magic and myths), aware of at least some of the social and political conflicts within Italian history, and familiar with crime fiction based on recognizable formulae.

The only existing critical examination of these authors is, to the best of my knowledge, one essay on Leoni (see De Angelis). A discussion of the different ways the three texts construct "knowledge" may contribute to analyses of historical crime fiction texts focusing on knowledge as the link between "crime" and "history."Malvaldi, born in 1974, has a dottorato di ricerca in chemistry and has stated in several interviews that he is a passionate rationalist whose favourite writer is Primo Levi. He is mainly known as the author of the best-selling series I delitti del BarLume, witty if formulaic murder mysteries set in a small town in Tuscany. He deliberately timed the publication of Odore di chiuso to coincide with the $150^{\text {th }}$ anniversary of the unification of Italy in the hope that, lighthearted as it was, the novel might encourage some reflection on what may help or hinder the process of national unity. ${ }^{8}$ In the Afterword, he explains why he set his text in 1895:

Siamo nel 1895 [...] L'8 dicembre, Guglielmo Marconi riesce ad inviare il suo primo segnale radio oltrepassando una collina, e il colpo di fucile con

\footnotetext{
${ }^{7}$ The other novels in the series are I delitti della Medusa (2000), I delitti della luce (2005), and La Sindone del diavolo (2014).

${ }^{8}$ See, for instance, Malvaldi, "A tu per tu."
} 
cui il suo maggiordomo annuncia l'avvenuta trasmissione sarà uno dei pochi casi in cui un'arma da fuoco determina il corso della storia senza ammazzare nessuno [...] Il 28 dicembre, i fratelli Lumière organizzeranno a Parigi la prima dimostrazione pubblica di una diavoleria chiamata "cinematografo", Maria Montessori sarà la prima donna a venire ammessa nella società Lancisiana (che riunisce i medici e i professori di medicina della capitale) e Pellegrino Artusi darà alle stampe la seconda edizione del suo La scienza in cucina e l'arte di mangiar bene [...]

In una parola, il mondo sta cambiando. Sta diventando un posto piú aperto, in cui è possibile comunicare piú facilmente, e in cui certe discriminazioni incominciano a mostrare la loro insensatezza. (193-4)

The title refers metaphorically to the stifling atmosphere of a dilapidated castle in Tuscany inhabited by a decaying aristocratic family, its servants, and two guests. The plot is the most conservative of crime fiction plots, the traditional "locked room mystery in a country manor," where the networks of causes and effects are detected and explained, and social order is re-established with the discovery and punishment of all guilty parties. However, Malvaldi subverts the genre formula through a variety of devices. Some are elements of the plot: the murder victim is the butler, the murderer is the head of the aristocratic family, and assorted skeletons in the cupboards of the family members and one of the guests are gradually discovered not by the sleuth alone, but with the collaboration and specialist knowledges of four outsiders, namely the police inspector (born in Calabria), the doctor (a Socialist, son of a local shepherd), a deviant offshoot of the noble family (an intelligent, down-to-earth young woman), and the other guest, Pellegrino Artusi. Another decentralizing strategy is dialogue with the readers, which is both indirect (meta-narrative comments in the epigraph and afterword) and direct (authorial asides and addresses to the readership). The epigraph is a line from the 1977 cult film Berlinguer ti voglio bene by Giovanni Bertolucci: "Sospensione d'i' rricreativo, principia avviare i' cculturale." It can be read as an ironic application to the novel of the notion that "entertainment" and "culture" are mutually exclusive, or as a metaphoric parallel between two historical institutions doomed to gradually change and disappear-aristocracy at the end of the nineteenth century and the Communist Party at the end of the twentieth. The afterword, entitled "Non è un caso," explains the author's choices of historical period, characterization, and 
inclusion of an (apocryphal) recipe in a book whose main character is the author of the first collection of Italian recipes.

Some direct addresses to the readers are based on the implied shared knowledge of genre clichés:

L'urlo disumano era opera della signorina Barbarici, che giaceva in terra a pelle di leone davanti a un portoncino di legno e ferro che si trovava al piano seminterrato; la poveretta era, oltre che immobile, debitamente svenuta, come del resto si conviene a una donna in un romanzo ambientato a fine '800. (39)

Other direct addresses connect past and present in brief historical digressions on post-unification Italy:

\begin{abstract}
"Cocaina, signor delegato. Preparato estratto da foglie di Erythroxylum coca in alcol etilico al dieci per cento. Da assumersi in quantità estremamente moderate." Prima che i lettori pensino che il delegato sia sul punto di arrestare il dottore per spaccio, sarà bene fare una precisazione: l'uso di cocaina a scopo terapeutico, alla fine dell' 800 , è perfettamente normale, ed è uno dei rimedi favoriti dai nobili e dai ricchi borghesi d'Italia per curare i sintomi delle malattie di stomaco. (176)
\end{abstract}

The network of intertextual references—which, as noted earlier, is one of the main features of historical crime fiction-is mostly, but not exclusively, literary. The description of awakening in the castle, experienced at sunrise by the staff and several hours later by the aristocrats, strongly recalls the opening of Giuseppe Parini's satirical poem Il Giorno (1763). The old baroness is known as nonna Speranza, which is the name of one of the characters representing outdated nineteenth-century values in Guido Gozzano's gently ironic poem "L'amica di nonna Speranza" (1910). The baroness and her granddaughter enjoy a novel that they could not under any circumstances have been reading in 1895, namely Joseph Roth's Die Kapuzinergruft (The Emperor's Tomb), published in 1938, which also describes the decline and end of a noble family. The first dinner in the manor's dining room, with family and guests eating and arguing under a frescoed ceiling, recalls the first dinner scene in Tomasi di Lampedusa’s Il gattopardo. Conan Doyle's Sherlock Holmes novels, despised by the noble family and appreciated by Artusi, provide 
a fruitful approach to crime detecting: "Eliminate l'impossibile. Quello che resta, per quanto improbabile, dev'essere per forza la verità" (162). . Artusi's explanations of the chemical processes that enable water and oil to become mayonnaise-a metaphorical warning that regional differences need time and care in order to blend-recall the metaphorical functions that chemical elements have in Primo Levi's Il sistema periodico, which for Malvaldi is "il libro perfetto" ("A tu per tu").

At the centre of Malvaldi's intertext is his main source of biographical data on Artusi, the brief Autobiografia, which Artusi wrote in 1902, after becoming famous. ${ }^{10}$ Malvaldi's and Artusi's texts interact in more ways than one. A few of the anecdotes told in the Autobiografia become part of fictional conversations between Artusi and other characters, and the main narrative alternates with playful pastiche in the form of four apocryphal "entries" in Artusi's "diary," with comments on the noble family, the food they eat, and the murder.

In somma delle somme, ero venuto qui per consigliare il signor barone sulle sue cucine e per passare una settimana tranquilla, e mi trovo a rischiare di essere imputato di omicidio, o promesso sposo di una vecchia demente che potrebbe essere chetata solo colla calce viva. Di conto mio, occorrerà che faccia come nella storia dei due sassi bianchi e trovi un modo per togliermi d'impiccio alla svelta; dopo di che, il buon barone di Roccapendente se vuol rivedermi dovrà aspettare di essere invitato a casa mia. (80)

Consistent with his autobiographical description, the character Artusi is not an intellectual but maintains a lively interest in literature and science as well as in business deals and cookery. His understanding of the effects of asparagus on human kidneys is what establishes the death of the butler as a murder rather than an accident, and his explanation of the reasons for choosing to write La scienza in cucina shows an awareness of the central place of both food and language in Italian national identity:

\footnotetext{
${ }^{9}$ The actual quote, from Chapter 6 of The Sign of Four (111) is "When you have eliminated the impossible, whatever remains, however improbable, must be the truth" (Doyle's italics).

${ }^{10}$ Autobiografia has recently been reprinted by different publishers, with forewords and afterwords by different scholars. I have used two editions: Autobiografia (1999) and Tutto vi dono (2012).
} 
Il baffone si raddrizzò sulla schiena, in modo militaresco, e concluse in modo perentorio:

"Un libro di cucina dovrebbe esser comprensibile a tutti, perché tutti noi mangiamo e abbiamo diritto di mangiar roba buona e cucinata bene; dovrebbe essere scritto in italiano, perché siamo italiani, e non in quel gergo francioso che viene inteso solo nelle regioni nordiche; e dovrebbe dare delle dosi, vivaddio, in grammi e in litri, che sono uguali per tutti, e non in once, mestolate o pizzichini o ombrette, quando si degnano di darti le dosi. E se un tale libro non esiste, lo scriverò io stesso. E cosí feci." (87)

The whole novel is in fact an intersection of various kinds of knowledge (social, medical, chemical, literary) and of reflections on knowledge. The investigators make a succession of hypotheses, each of which needs verification. In a humorous reference to epistemology, the police inspector is familiar with the notion of falsifiability nearly seventy years before the publication of Karl Popper's The Logic of Scientific Discovery:

Ma purtroppo, il delegato Artistico aveva scoperto da solo [...] (vari anni prima della nascita di un bambino di nome Karl Popper) che una teoria correttamente costruita è una teoria falsificabile. Non importa quanti siano gli elementi a suo favore: basta un singolo, semplice, stronzissimo controesempio e la teoria va a farsi benedire. (154)

By the end of the narrative, the knowledge that the murder had been committed in order to protect the existing social order brings about something more than the discovery and retribution of all guilty parties: it brings about the transition from the enclosed, self-referential world of the aristocracy to new paradigms. The only two young aristocrats with some potential for learning are given a chance: the young woman will go on to study medicine, and the elder son is encouraged to turn the ancestral mansion into a hotel:

Il delegato si alzò in piedi e si lisciò i pantaloni.

"Signor Gaddo, voi potete essere signore e padrone, senza alcun titolo, di un castello che diventerà un cumulo di macerie, o potete essere cittadino di un mondo aperto, in cui tutti possono entrare, e che potete 
amministrare comunque. La scelta sta a voi. Ma, fatemelo dire, voi avete una scelta. Ci sono persone che tale scelta non l'hanno, e non l'avranno giammai." (186)

Odore di chiuso ends with closure but-unlike most clue-puzzle texts-without total reassurance: although answers have been found to all of the puzzle's questions, there is no guarantee of security for most of the characters and for the newly unified nation.

Noir fiction has few if any of the certainties of clue-puzzle mysteries. It represents the dark side of murder mysteries, in which crime and murder are manifestations of a corrupt social order with little or no hope of progress. Noir narratives are usually set in cities, where nothing is as it seems, few people can be trusted, and physical disorientation parallels the loss of ethical direction. Knowledge tends to be acquired not epistemologically, through conjectures and falsifications, but ontologically, by successive, increasingly threatening, twists and shocks. Criminals are discovered and punished, but this does not bring about social renewal. ${ }^{11}$ The key figure is often the private eye, the tough, incorruptible man or woman who works independently of official law and order, ventures alone into the shadiest parts of the city, drinks heavily, and falls in love with the wrong people. ${ }^{12}$ The Dante novels of Giulio Leoni-a writer interested in non-traditional areas of knowledge, such as astrology, magic, and legerdemain — have much in common with noir fiction.

Using Giampaolo Dossena's popular biography Dante as his main source, Leoni gives his readers a Dante consistent with the well-known descriptions by Giovanni Villani and Giovanni Boccaccio:

Questi fue grande letterato quasi in ogni scienza, tutto fosse laico [...] Questo Dante per lo suo savere fue alquanto presuntuoso e schifo e isdegnoso, e quasi a guisa di filosafo mal grazioso non bene sapea conversare co' laici; ma per l'altre sue virtudi e scienza e valore di tanto cittadino ne pare che si convenga di dargli perpetua memoria in questa nostra cronica. (Villani 1348)

\footnotetext{
${ }^{11}$ Mandel (43-46); Scaggs (47; 58-64).

${ }^{12}$ See Tani (22-25); Knight (Crime Fiction 111-13); Iacoponi (17); and Meazzi (120-21).
} 
Niun altro fu piú vigilante di lui e negli studii e in qualunque altra sollecitudine il pugnesse [...] Dilettossi similemente d'essere solitario e rimoto dalle genti, acciò che le sue contemplazioni non gli fossero interrotte [...] $\mathrm{Fu}$ ancora di maravigliosa capacità e di memoria fermissima e di perspicace intelletto [...] Vaghissimo fu e d'onore e di pompa per avventura piú che alla sua inclita virtú non si sarebbe richiesto. (Boccaccio 1360)

Leoni's Dante is, like Villani's and Boccaccio's, a sharp-minded loner, often short-tempered and arrogant, and both an intellectual and a man of action. He has many of the standard character traits of fictional private eyes. Like Dashiell Hammett's and Raymond Chandler's heroes, he "operates alone, judges others by himself, shares no one's values and mores" (Knight, Crime Fiction 112); he is "capable of dealing efficiently with a disorderly and dangerous world" (Tani xi) because he has physical courage, some fighting skills, a rational mind, good memory, curiosity, and defiance of authority; he also shares some of the basic problems of fictional private eyes, such as constant impecuniousness (the novels contain frequent references to Dante's recurrent migraines and to his documented debts) and fondness for alcohol and women. Leoni's Dante is close to Tani's "doomed detectives," who stumble along in a contradictory reality to an unrewarding solution. The two novels I examine are set during brief periods of Dante's life in which he had some limited political power: his two months in office as a Prior of Florence (mid-June to mid-August 1300) (Mosaico) and the weeks he spent in Rome in September-November 1301 as the leading member of a delegation sent by Florence to pledge the city's loyalty to Pope Boniface VIII (Crociata).

"[Nei miei romanzi] di quello che dice Dante"-Leoni states in an interview_- "niente è lasciato al caso: o ripete cose che ha detto da qualche parte nelle sue opere o comunque faccio perno sulle sue idee" (Leoni, "I mille volti"). In order to appreciate Leoni's intertext, the implied readers constructed by the novels need to be familiar with Dante's works, especially the Commedia (which is still a part of the Italian syllabus in licei), and to know at least something of thirteenth-and fourteenth-century Italian history and culture. Various characters recite parts of Dante's poems to gain favour with him; his evaluation of the vernacular spoken in Rome as a "parlata barbara" (Crociata 309) recalls the labels tristiloquium and turpissimum used in Chapter XI of De vulgari eloquentia. Historical characters who had significant connections with Dante Alighieri appear in one or more novels: Guido Cavalcanti (who is in fact the murderer in the first novel of the series); the 
painter Giotto; the poet Cecco Angiolieri; the thief Vanni Fucci; Pope Boniface VIII and his envoy to Florence, Cardinal Matteo di Acquasparta; the woman Dante addressed in his rime petrose, who in Leoni's novels is a prostitute called Pietra; and the astrologer Guido Bonatti, whom Dante never met, but whom he admired (and whom he placed in Hell with the soothsayers in Inferno XX).

Each novel also contains several recognizable references to the Commedia. A funnel-shaped underground graveyard gives Dante the idea for the shape of Hell in his not-yet-written great poem (Mosaico 109); a theatrical scene painted by street actors, with a white rose in the middle of concentric circles, makes him wonder about what may be the shape of Paradise (Mosaico 272); a fleeting memory of Brunetto Latini makes him decide that the most fitting punishment for sodomites would be a rain of fire (Crociata 74). In addition, numerous phrases or entire lines are re-contextualized in fictional scenes and dialogues. They are not evidenced by markers such as italics or inverted commas since Dante hears or thinks them in the course of his investigations; however, readers know that he will recall them later, when he writes his masterpiece. In a dream, Dante talks with the ghost of Guido Cavalcanti, who cryptically predicts Dante's future, concluding: "Ma delle cose future non voglio saziarti, cosí che tu possa scoprirle a una a una, con dolore. Piú non ti dico e piú non ti rispondo" (Mosaico 240). ${ }^{13}$ In Rome, looking at a group of pilgrims, Dante muses about their homeless condition: "Lasciare la propria casa, la propria patria [...] Dormire sulla fredda pietra, salire e scendere le scale degli altri in attesa di un tozzo di pane [...] Credo che sia la peggiore delle sventure" (Crociata 151). ${ }^{14}$ Later on, Dante and a Senator are discussing the unworldly Pope Celestine V, who resigned and was succeeded by Boniface VIII, whose main interest is temporal power:

\footnotetext{
"Se volete" disse [il senatore] poi, stringendo i denti. "Sono in molti a rimpiangere il pio eremita. Siete anche voi tra di loro?"

"Meglio avrebbe fatto a non spianare la strada al Caetani, con il suo gran rifiuto" rispose secco il poeta. (Crociata 87$)^{15}$
}

\footnotetext{
${ }^{13}$ Inferno VI, 90 (the final words of Ciacco's prophecy).

${ }^{14}$ In Paradiso XVII, Dante's ancestor Cacciaguida prophesies: "Tu proverai sí come sa di sale / Lo pane altrui, e com'è duro calle / Lo scendere e 'l salir per l'altrui scale" (58-60).

${ }^{15}$ Dante in fact places Celestine V in the vestibule of Hell, among the "uncommitted" who are despised by both Heaven and Hell (Inferno III, 60): "l'ombra di colui / che fece per viltate il gran rifiuto."
} 
Leoni's implied readers are also familiar with the formulae of private eye fiction. Dante wanders on the dark side of Florence and Rome, encountering dirt, poverty, petty crime, and prostitution as he investigates chains of murders connected with groups of people who are planning a major disruption to society. Far from being common criminals, these conspirators are intellectuals and men of action who hope to replace the existing corrupt social order with a new one based on new, esoteric knowledge. Each group includes one beautiful woman to whom Dante is attracted. In each novel Dante discovers, but does not defeat, the conspiracy, which is eventually crushed not by any official authority, but by its own misguided machinations. No order, whether new or old, replaces the chaos, and the prevailing mood at the conclusion is disillusionment verging on despair. At the end, like many fictional PIs, Dante is alone; what he has learned won't help anyone but will provide him with inspiration for the language and structure of his great work.

The plots of the novels reflect Leoni's interest in alternative forms of knowledge and esoteric beliefs and practices (De Angelis 56-57). I delitti del mosaico, set in June 1300 and therefore chronologically Dante's first investigation, starts with the discovery of the corpse of a master mosaicist next to a huge unfinished mosaic, which apparently depicts the Old Man of Crete, a symbol of the ages of humankind mentioned in Inferno XIV. In his capacity as Prior, Dante investigates and comes across a circle of scholars, one of whom is later murdered. Dante eventually discovers that the only man who possesses knowledge relevant to the two murders is the one member of the circle who is not a scholar, but a warrior-a Knight Templar in disguise. The unfinished mosaic was meant to represent the New World, the mythical Fifth Land after Europe, Asia, Africa, and the Oceans, "[u]na terra sconfinata, un'isola a forma di clessidra: due grandi masse legate tra loro da un istmo" (309). The murderer reveals that his brother Templars discovered the New World but committed themselves to keeping its existence secret because its huge stores of precious metals were likely to cause endless wars. He buys his freedom from Dante with a map of winds and sea currents, useful to anyone seeking the Fifth Land, ${ }^{16}$ then tries to flee on a ship that catches fire and sinks with all its passengers.

As in Malvaldi's novel, various fields of knowledge-the scholars of the circle are experts in areas such as astrology, chemistry, theology, and jurisprudence-intersect throughout the book. Crime is also represented as an object of

\footnotetext{
${ }^{16}$ For the significance of maps in post-modernist detective stories, see Tani (47-51).
} 
knowledge. As Dante explains, "Penso anche che non esista macchinazione della mente che la ragione e la virtú non possano decifrare. Perché l'omicida lascia sul corpo della vittima l'impronta della propria anima, insieme con quella delle mani" (73-74). Quests for knowledge, however, have clear limits, and individuals or groups who attempt to trespass inevitably fail. The traditional interpretation of Dante's Ulysses as the individual whose "virtue" lies in striving to extend human "knowledge" is negatively re-contextualized in Leoni's narrative: the raised oars of the fleeing ship strike Dante as the wings of a "volo folle" (318), ${ }^{17}$ and the Templar and his woman (a native of the Fifth Land) burn together like "due lingue di fuoco agitate dal vento" (319), very similar to the forked tongue of flame that imprisons Ulysses and Diomedes in Inferno XXVI. Dante retains the mental image of a mountain in the middle of the Fifth Land, which will become the mountain of Purgatory in his yet-unwritten masterpiece, but burns the map:

Di scatto avvicinò l'orlo della pergamena alla fiamma della lucerna.

La fissò a lungo, mentre veniva consumata dalle fiamme. Alle spalle gli parve di avvertire una presenza amica, che scrutava le sue azioni.

"Ho ben agito, padre?"

"Sí" rispose la voce antica che viveva nella sua anima. "Ma non ne avrai merito. Hai velato gli occhi dei tuoi compagni, hai versato la cera nelle loro orecchie. Perché, come Ulisse, vuoi essere l'unico a sapere." (I delitti del mosaico 315)

La crociata delle tenebre is set in Rome, described as a city with extremes of wealth and poverty, corrupt public officials, and warring noble families, a city where ignorance and fear are fostered by the power of the Church. Dante comes across a series of prostitutes disembowelled in accordance with a mysterious ritual and slowly discovers that these murders are part of a plan by a Senator and his daughter to re-introduce the worship of the Egyptian goddess Isis (invoked by her followers as "Vergine Madre, figlia del tuo figlio"18) (136) in the hope that the new religion will destroy the Christian Church and become the foundation of a new Roman empire. Dante unsuccessfully tries to stop the Senator, who kills himself while his daughter and their followers drown in an insane attempt to

\footnotetext{
${ }^{17}$ Inferno XXVI, 125: "De’ remi facemmo ali al folle volo."

${ }^{18}$ St. Bernard's address to the Virgin Mary at the opening of Paradiso XXXIII.
} 
block the river Tiber, flood Rome and the Vatican, and clear the way for the rise of the new civilization.

The parallels with Mosaico are evident. In both novels, the murder plot takes second place to lengthy expository dialogues on the nature of love, free will, the decline of empires, the place of Jews in a Christian society, and the Jewish legend of the golem. As one of the characters says to Dante, possibly with yet another reference to the Canto of Ulysses, "Sapere [...] è la fiamma che ci consuma" (145). In both narratives, Dante is the only person who-just as in Inferno-descends through the depths of other people's wickedness; the only person to whom the chief conspirators reveal their aims before dying; and the only person who has access to the conspirators' knowledge. Mosaico ends with him affirming his own individual gifts ("L'immortalità. Sí, l'avrebbe avuta") (320); Crociata ends with his disenchantment with his country—split by politics and united by corruption rather than faith—and individual longing for salvation, symbolized by the final word, "stelle" (358). In both novels, the conservative construction of all social changes as changes for the worse mirrors the negative view of the present (and of literature) put forward in Leoni's blog:

Azzerata ogni forma di ottimismo positivista sulle sorti magnifiche e progressive [della storia], [...] seppellito definitivamente ogni dio che potesse darle luce e senso, non si può fare altro che perdersi, [...] cercare rifugio in ciò che non è piú, il passato, o ciò che non è ancora, il futuro. ("L'epica della New Italian Epic" 2011)

Apparently just an entertaining literary subgenre, historical crime fiction can lead to reflections about the changing conceptualizations of "crime," "detection," and "solutions." In the novels featuring historical figures as sleuths, these figures both embody and critique the knowledge and values of their times, in their own words and in words the authors provide. Readers of Odore di chiuso will find a light-hearted plot in which humour and irony are used to pose ethical and political questions about Italian history. Readers of I delitti del mosaico and La crociata delle tenebre will find adventurous journeys, complicated plots, hand-to-hand fighting, passionate sex, debates about science and culture, and the belief that there may be valuable knowledge outside established religion, education, and politics.

The three novels are also evidence that, as both McHale (11) and Scaggs (125) state, the "epistemological" and the "ontological" dominants are not 
mutually exclusive. Pellegrino Artusi, not directly connected with any institutions of power, speaks with the authority of a life spent working and learning, something Primo Levi would have called "l'autorità di chi insegna le cose perché le sa, e le sa per averle vissute" (1423); yet the relatively optimistic epistemological slant is tempered by the author's twenty-first-century historical hindsight about a unified Italy. Dante's authority in I delitti del mosaico and La crociata delle tenebre comes from cultural and political institutions, all corrupt; he is the voice of the pessimistic ontological slant of the novels, but he also, at the same time, represents the texts' limited epistemological hope, placed in exceptional individuals who are, against all odds, determined to seek knowledge and pass it on to others through their creative works.

Monash University

\section{Works Cited}

Artusi, Pellegrino. Autobiografia. 1902. Ed. Alberto Capatti. Bra: Slow Food Editore, 1999. Tutto vi dono. Autobiografia del padre della cucina italiana. Ed. Alberto Abruzzese and Andrea Pollarini. Milan: Il Saggiatore, 2012.

Boccaccio, Giovanni. Trattatello in laude di Dante (approx. 1360), ed. De Bibliotheca. Chapter XX. http://bepi1949.altervista.org/biblio2/tratta/ tratta2.htm.

Calvino, Italo. “Risposte a 9 domande sul romanzo." In Saggi 1945-1985. Ed. Mario Barenghi. Vol. 1. Milan: Mondadori, 1995. 1527-30.

Comastri Montanari, Danila. Giallo antico. Come si scrive un poliziesco storico. Trebaseleghe: Hobby \& Work Publishing, 2007.

De Angelis, Gabriella. "Giulio Leoni ou 'rien n'est comme il parât'." Roman policier et histoire. Spec. issue of Cahiers d'études romanes 15 (2006): 55-75.

Del Bosco, Fabio. La storia e la favola. Il modello manzoniano nel romanzo storico contemporaneo. Ravenna: Longo, 2007.

Dossena, Giampaolo. Dante. Milan: Longanesi, 1995.

Doyle, Sir Arthur Conan. The Penguin Complete Sherlock Holmes. Harmondsworth: Penguin Books, 1981. 
Eco, Umberto. "Postille a Il nome della rosa 1983." Afterword. Il nome della rosa. 15th ed. Milan: Bompiani, 1985. 505-33.

Galli, Giorgio. Introduction. Delitti per diletto. Storia sociale del romanzo poliziesco. By Ernest Mandel. Milan: Interno Giallo, 1990. i-xiv.

Ginzburg, Carlo. "Spie. Radici di un paradigma indiziario.” In Ginzburg, Miti emblemi spie. Morfologia e storia. Turin: Einaudi, 1986. 158-209.

Iacoponi, Tiziana. "Detective per caso ovvero donne in cerca di guai." In Trent'anni di giallo italiano. Omaggio a Loriano Macchiavelli e Antonio Perria. Ed. Marie-Hélène Caspar. Spec. Issue of Narrativa 26 (2004): 111-18.

Knight, Stephen. Crime Fiction 1800-2000:Detection, Death, Diversity. Basingstoke: Palgrave Macmillan, 2004. . "The Golden Age." In The Cambridge Companion to Crime Fiction. Ed. Martin Priestman. Cambridge: Cambridge UP, 2009. 77-94.

Leoni, Giulio. La crociata delle tenebre. Milan: Mondadori, 2007. . I delitti del mosaico. Milan: Mondadori, 2004. "L'epica della New Italian Epic e il bastone di Sherlock Holmes." Giulio Leoni’s blog. 21 July 2011. http://giulioleoni/blogspot.it. "I mille volti di Dante Alighieri, detective nella sua Firenze." Interview with Paolo Izzo. 16 Mar. 2004. http://www.paoloizzo.net/leoni.htm.

Levi, Primo. La ricerca delle radici. 1981. Rpt. in Opere. Ed. Marco Belpoliti. Vol. 2. Turin: Einaudi, 1997: 1359-1528.

Malvaldi, Marco. "A tu per tu con Marco Malvaldi." Interview with Laura Vicenzi. 26 June 2011. bassanonet.it. http://cultura.bassanonet.it/interviste/8918 .html.

Odore di chiuso. Palermo: Sellerio, 2011.

Mandel, Ernest. Delitti per diletto. Storia sociale del romanzo poliziesco. 1989. Trans. Bruno Arpaia. Milan: Interno Giallo, 1990.

McHale, Brian. Postmodernist Fiction. New York and London: Methuen, 1987.

Meazzi, Barbara. "Il ventre della città nel romanzo giallo contemporaneo: Torino, Bologna e Napoli." In Trent'anni di giallo italiano. Omaggio a Loriano Macchiavelli e Antonio Perria. Ed. Marie-Hélène Caspar. Spec. issue of Narrativa 26 (2004): 119-38.

Milanesi, Claudio. Introduction. In Roman policier et histoire. Ed. Claudio Milanesi. Spec. issue of Cahiers d'études romanes 15 (2006): 9-20.

O'Gorman, Ellen. "Detective Fiction and Historical Narrative." Greece and Rome, 2nd ser. 46.1 (April 1999): 19-26. 
Perissinotto, Alessandro. La società dell'indagine. Riflessioni sopra il successo del poliziesco. Milan: Bompiani, 2008.

Reuter, Yves. Il romanzo poliziesco. 1997. Trans. Flavio Sorrentino. Rome: Armando, 1998.

Rushing, Robert. Resisting Arrest: Detective Fiction and Popular Culture. New York: Other Press, 2007.

Scaggs, John. Crime Fiction. Oxford: Routledge, 2005.

Tani, Stefano. The Doomed Detective:The Contribution of the Detective Novel to Postmodern American and Italian Fiction. Carbondale and Edwardsville: Southern Illinois UP, 1984.

Vickers, Anita. "Stephanie Barron: (Re)Inventing Jane Austen as Detective." In The Detective as Historian: History and Art in Historical Crime Fiction. Ed. Ray B. Browne and Lawrence A. Kreiser, Jr. Bowling Green, OH: Bowling Green State University Popular Press, 2000. 213-21.

Villani, Giovanni. Cronica (approx. 1348). Ed. G. Porta. Book IX, Chapter 136: "Chi fue il poeta Dante Alighieri di Firenze." http://www.letteraturaitaliana. net/pdf/Volume_2/t48.pdf

Wu Ming 2. Utile per iscopo? La funzione del romanzo storico in una società di retromaniaci. Rimini: Guaraldi, 2014. 
